\title{
Quality Attributes of Some Fruit and Vegetable Crops Preserved by Three Different Drying Methods
}

\author{
Sabreen, S. Abd El- Ghaffar'1, Ziena, H.M.S. ${ }^{1}$, Youssef, M. M. ${ }^{2}$ \& Shokr, A. Z. ${ }^{3}$ \\ ${ }^{1}$ Food Science \& Technology Dept., Fac. of Agric., Alexandria Univ. (Damanhour Branch), Egypt. \\ 2 Food Science \& Technology Dept., Fac. of Agric., Alexandria Univ., El-Shatby, Alexandria, Egypt. \\ ${ }^{3}$ Agric. Engin. Dept., Fac. of Agric., Alexandria Univ., El- Shatby, Alex., Egypt.
}

\begin{abstract}
Three different drying methods (sun drying, hot air and solar drying) were investigated to evaluate their performance and effects on quality attributes of six crops. These crops included three fruit crops (grapes, figs and apricots) along with three vegetable crops (tomato, okra and jew's mallow). A solar collector was designed and used in the present study. Values of drying constant $(K)$ and coefficient determination $\left(\mathrm{R}^{2}\right)$ were evaluated for each of the aforementioned crops and the Fick's equation diffusion equation was applied. Consequently, the optimum time of drying was interpretated for each crop.

No significant differences could be traced regarding dehydration and rehydration ratios of any of the six crops dried by the three methods under study. Furthermore, losses in some chemical components (sugars, total and fixed acidities, and $\mathrm{SO}_{2}$ ) due to drying by different methods were insignificant for each of the crops under investigation. On the other hand, severe destruction of vitamin $\mathrm{C}$ could be observed for all dried crops regardless the drying method applied as compared to their fresh correspondings. Microbial analysis exhibited higher bacteria and yeast and mould count $(\mathrm{CFU} / \mathrm{g})$ for almost all crops preserved by sun drying than their counterparts preserved by hot air and solar energy. The panelists preferred the colour of grapes, apricots, tomato and jew's mallow dried by solar energy and hot air than their correspondings dried naturally. On the other hand, no significant differences could be observed regarding scores given by the panelists for flavour and texture for all crops under study, with jew's mallow being the only exception and so it was less acceptable.
\end{abstract}

Keywords: sun drying, solar drying, dehydration, fruits, vegetables, dehydration ratio, sugars, vitamin C, acidity, $\mathrm{pH}$, sulfur dioxide.

\section{INTRODUCTION}

Sun drying is done by placing pieces of foods on drying trays and then the food is covered with a layer of cheese cloth. After the food is almost dry, the food is put in an airy, shady place to prevent scorching during the final stage of drying. Vegetables take 3 to 7 days to dry in the sun (Oschwald, 1984). Grapes were sun dried by bunches spread on cloth or in paper boxes or hung under transparent plastic film, exposed to direct sun light. Drying was conducted slowly for 2-3 weeks until a moisture content of about $16 \%$ was reduced (Saravacos, 1986). Grapes could be treated by dipping in a solution of $2.5 \%$ potassium carbonate $+0.5 \%$ olive oil for one minute. This pre-treatment "checks" the skin and increases drying rate (Kosteropoulos \& Saravacos, 1995). Furthermore, Grapes could be treated by dipping in commercial dipping oil or ethyl oleat or olive oil followed by dipping in potassium carbonate solution and hot sodium hydroxide solution then, grapes were dried in dryer at $60^{\circ} \mathrm{C}$ and air velocity $0.5(\mathrm{~m} / \mathrm{s})$ (Pangavhane et al., 1999). The dewaxing agent such as sodium hydroxide could be used for dewaxing process of grapes prior to dehydration (Carpi et al., 1999). Figs were dried in drying tunnel by air of a temperature ranged from $85^{\circ} \mathrm{C}$ to $95^{\circ} \mathrm{C}$ for $3 \mathrm{hr}$. Dried figs were moved to dry in a second drying tunnel at $85^{\circ} \mathrm{C}$ for 14 hrs. (Papoff et al.. 1998).

Tomatoes were immersed in boiling solution of $2.5 \% \mathrm{NaCl}$, blanched for $60 \mathrm{sec}$ and dipped in cold water. Tomatoes were blanched in brine or water, cut into $1.5 \mathrm{~cm}$ thickness slices, and dipped for 2 min (at room temperature) in $2.5 \%$ starch solution containing $5 \%$ potassium metabisulphite. Slices were dried to about $4 \%$ moisture content (Tripathi $\&$ Nath, 1989).

Numerous designs for solar dryers have been published. The collector of solar fruit dryer consists of blackened rock for heat storage, and a plastic cover was placed above the rock on a wooden $2 \times 4 \mathrm{~m}$ frame. The bed was filled with granite to 
store solar energy (Moyls, 1986). Solar collector leading into a tunnel dryer being arranged parallely to reduce the air resistance. The frame of the collector and tunnel dryer $(20 \mathrm{~m}$. long and $6 \mathrm{~cm}$ high) is fixed on the ground. The collector was 1 $\mathrm{m}$. wide, the tunnel dryer $2 \mathrm{~m}$. Both components are covered by a transparent PE- EVA air - bubble foil. (EL-Shiaty et al., 1991). Ageodesic dome solar fruits dryer was designed and constituted for drying grapes. The base diameter of the dome was 20 feet. Ground below the dome was covered with gravel for thermal energy storage or with a plastic sheet to minimize the effect of ground moisture. Fruit trays were located inside the inner dome, so that the fruits are not exposed to direct sun. The heated air passed through the fruit trays inside the dome before existing at the top of the dome (Goswami et al.. 1991). Solar drying system for drying some fruits and vegetables was designed by using eight flat plate solar collectors. Each flat plate solar collector had a gross area of $1.86 \mathrm{~m}^{2}$., cross section area of air tunnel with $0.048 \mathrm{~m}^{2}$. The collector has a gross cover which acts as a barrier between the wind and absorber plate (Ahmed \& Khan, 1997). The passive solar drying system constructed with tunnel $(1 \times 2 \times 0.5 \mathrm{~m})$ with plastic cover sheet in two ventilation openings. The active drying system consisted of flat plate solar collector $(2 \times 1 \mathrm{~m})$. The collector was connected to $0.8 \times 0.7 \times 0.3 \mathrm{~m}$. metal thin layer containing six circular trays (Yosif, 2002).

The present study was carried out to achieve the following goals :

- Design a solar dryer to dry some fruits and vegetables.

- Evaluation of three drying methods (i.e. solardrying, hot air and sun drying) for drying the fruits and vegetables under study.

- Investigation of the physical, chemical, microbiological and sensory properties of fruits and vegetables dried by the aforementioned three drying methods.

\section{MATERIALS AND METHODS}

\section{Materials}

Different kinds of fresh fruits and vegetables were used in the present study. The fruits included: Grapes (Vilis vinifera), Sultana variety, Apricot (Prunus amreniaca), Canino variety and fig (Ficus carica), Sultani variety.
The vegetables included: Tomatoes (Lecopersicon esculentan), Castla rock variety, Okra (Hibiscus esculentus), Balady variety and Jew's Mallow (Corchorous olitorius), local cultivated. The samples were obtained directly after harvest from some farms in Behera Governorate during the seasons of 2002 - 2003.

\section{Methods}

An indirect solar dryer (Fig 1) was designed and used in the present experiments. No electrical input was used in the dryer. The solar dryer consists of solar collector, drying chamber and chimney. The solar collector had dimensions of $0.75 \mathrm{~m}$ by $3 \mathrm{~m}$. and using a corrugated steel sheet thickness of $0.8 \mathrm{~m} . \mathrm{m}$ and painted black to absorb the incident solar energy. The glass cover was $6 \mathrm{~m} . \mathrm{m}$ thickness and placed from the top of the corrugations on the steel sheet and formed the top of the air flow channel. The collector was connected to a drying chamber containing 3 stainless steel trays $(1 \mathrm{~m}$, $0.75 \mathrm{~m}$ and $0.6 \mathrm{~m}$ ). The heated air enters the drying chamber underneath the trays and flows upwards through the samples and goes out upwards through the chimney. All the outside parts of the solar dryer were painted black to increase the absorbance of solar energy.

Fruits and vegetables under study were prepared for drying by various techniques. Grapes were washed in water then dipped in a solution of $2.5 \%$

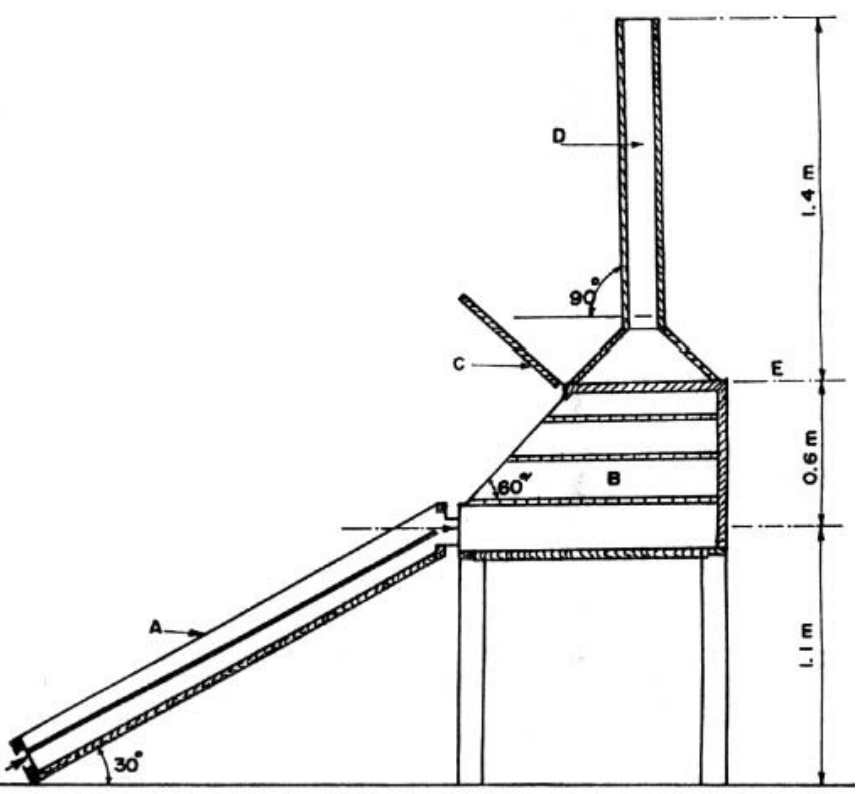

Fig. 1: General view of solar dryer

$A$ : Solar collector, $B$ : Cabinet dryer, $C: R e-$ flection dryer, $D:$ Chimney, $E$ : Door 
potassium carbonate $+0.5 \%$ olive oil for $1 \mathrm{~min}$ followed by blanching in $0.5 \%$ sodium hydroxide solution and cooled by chilled water. Sulphiting was carried out by dipping in $0.04 \%$ potassium metabisulphite solution for $15 \mathrm{~min}$. according to Kosteropoulos \& Saravacos, (1995). Figs were immersed in $4 \% \mathrm{NaCl}$ solution at $100^{\circ} \mathrm{C}$, then sulphiting was conducted by the exposure to fumigation of sulfur in a wooden box for 4-6 hr. at a rate of $20 \mathrm{~g}$ sulfur $/ \mathrm{kg}$ according to Gouda, (1974) Apricots were cut into halves and pitted. Sulphiting was carried out by placing the cut fruits upside up and were exposured to sulfur fumigation as mentioned previously. according to Von Loesecke, (1955). Tomatoes were immersed in boiled $2.5 \% \mathrm{NaCl}$ solution, blanched for $60 \mathrm{sec}$, cut into slices of $1.5 \mathrm{~cm}$. thick followed by keeping on a sieve to drain - off free juice. Sulphiting was undertaken by dipping in $2.5 \%$ starch solution containing $5 \%$ potassium metabisulphite for 2 min. according to Tripathi, \& Nath, (1989). Okra and jew's mallow were dipped in boiling water for $30,15 \mathrm{sec}$, respectively, and cooled by chilled water according to Adom et al. (1997). The solar dryer was fitted with copper- constant thermocouples fixed at the top of the chimney, cabinet dryer inlet and outlet of air solar-air-collector. All temperature data were measured through thermocouples thermometer digital sensor which were connected to manual selective switch distributer.

After preparation and pre-treatments were carried out, each type of fruits and vegetables were divided into three portions. The first portion was sun dried by spreading in thin layer and exposing to direct solar radiation. The second part was dehydrated as follows:

The grapes were loaded on drying trays in thin layer, drying by hot air was carried out at $55^{\circ} \mathrm{C}$ until moisture content was reduced to $15-20 \%$ (nearly $12 \mathrm{hr}$ ) (Von Loesecke, 1955). The figs were dried at $50^{\circ} \mathrm{C}$ until the moisture content reached $20 \%$ (Gouda, 1974). The apricots were dried at $55^{\circ} \mathrm{C}$ for 15-20 hr until a moisture content of $15-20 \%$ was reached (Bhutani \& Sharma, 1988). The tomatoes were dried at $78^{\circ} \mathrm{C}$ for $4 \mathrm{hr}$ and subsequently at $53^{\circ} \mathrm{C}$ until moisture content of about $5.5 \%$ was reached (Tripathi \& Nath, 1989). The okra was dried at $55^{\circ} \mathrm{C}$ until brittle texture was obtained (Shivhare et al., 2000). The leaves of the jew's mallow were dried at $55^{\circ} \mathrm{C}$ for $4 \mathrm{hr}$ (Kordylas, 1991).

The third part was solar dried by spreading the pre-treated materials on the trays in thin layer and drying was continued until the required moisture content was achieved.

\section{Physical methods:}

Dehydration ratio: Dehydration ratio was expressed as the ratio between the weight of fresh sample and the weight of dehydrated sample (Gouda, 1974).

Rehydration ratio: Rehydration ratio was determined by placing ten grams of dried products in $600 \mathrm{ml}$ beaker and a definite volume $(100 \mathrm{ml}$.) of tap water was added. The beaker was covered with watch glass, then heated to boiling within 3 min. and heating continued for $30 \mathrm{~min}$, the contents were transferred to a Buchnner funnel and left for 1 min before weighing. Rehydration ratio was calculated as follows: - The weight of dried sample: The weight of rehydrated sample (Gouda, 1974).

\section{Analytical methods}

Moisture content was determined by drying at $70^{\circ} \mathrm{C}$ according to Tripathi \& Nath (1989). Vitamin $\mathrm{C}$ was determined by 2, 6 dichlorophenolindo- phenol according to AOAC method (1984). Sugars were determined as total sugars following phenol sulfuric method, and reducing sugars were determined according to the Lane - Eynon method as outlined by Egan et al. (1981). Acidity was determined by titration of the extract with $0.05 \mathrm{~N}$ solution of sodium hydroxide in the presence of phenolphthalein indicator. Volatile acidity was determined by steam evaporation of the extract and titration with $0.05 \mathrm{~N}$ solution of sodium hydroxide in the presence of phenolphthalein indicator. Fixed acidity was calculated by difference as discribed by Egan et al. (1981). Sulfur dioxide was determined in the presence of sulfuric acid $(1+3)$ and $0.5 \mathrm{~g}$ sodium bicarbonate, by titration with $0.02 \mathrm{~N}$ iodine solution using starch solution as an indicator according to AOAC method (1984).

\section{Microbiological evaluation}

Samples were prepared under aseptic conditions. The necessary dilutions were made and the pouring plate technique was followed. The count of mesophilic aerobic bacteria on nutrient agar medium (N.A) and yeast and moulds on sabouraud dextrose agar medium (S.D.A.) were determined according to Dificos's Manual (1984).

\section{Organoleptic evaluation}

Samples were presented simultaneously to eleven well trained panelists. They were requested 
to rank each sample on a hedonic scale as follows: 9-10 (Excellent), 7-8 (Very good), 5-6 (Good), 3-4 (Fair) and 1-2 (Very poor) as outlined by Kramer \& Twigg (1962).

\section{Statistical analysis}

Data were statistically analyzed using Analysis of Variance (ANOVA) and means were further subjected to Duncan's Multiple Range test as outlined by Steel \& Torrie (1980).

\section{RESULTS AND DISCUSSION}

\section{Mathematical analysis}

Values of moisture ratios with their corresponding drying times are given in Figuers (2) and (3). They were used to obtain the drying constant and predicted equation of drying time. The drying constant is a combination of the transport properties and it may be defined by the following fully exposed equation as outlined by Shokr (1974, 1986).

$$
\frac{\mathrm{dM}}{\mathrm{dT}}=-\mathrm{k}(\mathrm{M}-\mathrm{Me})
$$

Where, M: is the moisture content at any time, Me: is equilibrium moisture content, $\mathrm{T}$ : is the time and $\mathrm{K}$ : is the drying constant. The fully exposed (thin layer) equation has been used for estimating and predicting the drying rate of several crops and for generalization of drying curves. The drying constant is suitable for the purposes of process design and optimization. The following equation is used to describe the thin layer drying curve of many products for its simplicity and high computational speed. In common practice, data of moisture content are transformed into the dimensionless symbol called moisture ratio denoted by MR and defined as:

$$
\mathrm{MR}=\frac{\mathrm{M}-\mathrm{Me}}{\mathrm{Mo}-\mathrm{Me}}=\exp (-\mathrm{kt})
$$

Where, Mo is the initial moisture content. The second form was determined by the linearization of the above model

$$
\operatorname{Ln}(\mathrm{MR})=\mathrm{KT}
$$

Where, $\mathrm{K}$ is the slope. Since the ambient air temperature and relative humidity are changeable, the equilibrium moisture content will be also changeable throughout the experiments, and thereby, the moisture should be corrected as follows:

$$
M R *=\frac{M}{M o}=e^{-K t}
$$

Where MR* is the corrected moisture ratio.

This equation fits the data obtained in our experiments. The values of $K$ and $R^{2}$ were evaluated for each test as given in Table (1). As the average temperature is almost the same, the drying constant $\mathrm{K}$, which indicates the drying rate, depends on the nature of the material. The moisture ratio was simplified to $\mathrm{M} / \mathrm{Mo}$ instead of the $(\mathrm{M}-\mathrm{Me})$ / (Mo - Me) used by Diamante \& Munro (1991). There were three reasons for this simplification. Firstly, in solar drying, the relative humidity $(\mathrm{RH})$ of the drying air continuously fluctuated so at best a mean Me could be calculated. Secondly, accurate Me data are not available at the high drying chamber temperatures reached. Thirdly, approximate calculations indicated that Me was less than $2 \%$ at the high temperatures and resultant low air relative humidities in the drying chamber during most of a drying run. So, the error involved in the simplification was very small. The coefficient of determination $\left(\mathrm{R}^{2}\right)$ was the primary criterion for selecting the best equation to describe the solar drying curves of fruits and vegetables.

Table 1: Values of drying constants for fruits and vegetables under study

\begin{tabular}{lcc}
\hline Material & $\mathbf{K}$ & $\mathbf{R}^{\mathbf{2}}$ \\
\hline Grapes & 0.0422 & 0.9761 \\
Figs & 0.0625 & 0.9667 \\
Apricots & 0.0603 & 0.9706 \\
Tomatoes & 0.1310 & 0.9112 \\
Okra & 0.2062 & 0.9285 \\
Jew's mallow & 0.1980 & 0.9380 \\
\hline
\end{tabular}

K: Drying constant

$\mathrm{R}^{2}$ : Coefficient of determination

\section{Physical properties}

Physical properties of the dried fruits and vegetables are given in Table (2). Dehydration ratios of samples dried by three different drying methods under study being quite comparable regardless the drying method utilized. This was also true regarding the rehydration ratios since no significant differences could be traced among samples dried by the aforementioned drying methods. Oliveira \& Oliveira (1999) reported that the heat applied during drying reduces the hydration of starch and the 


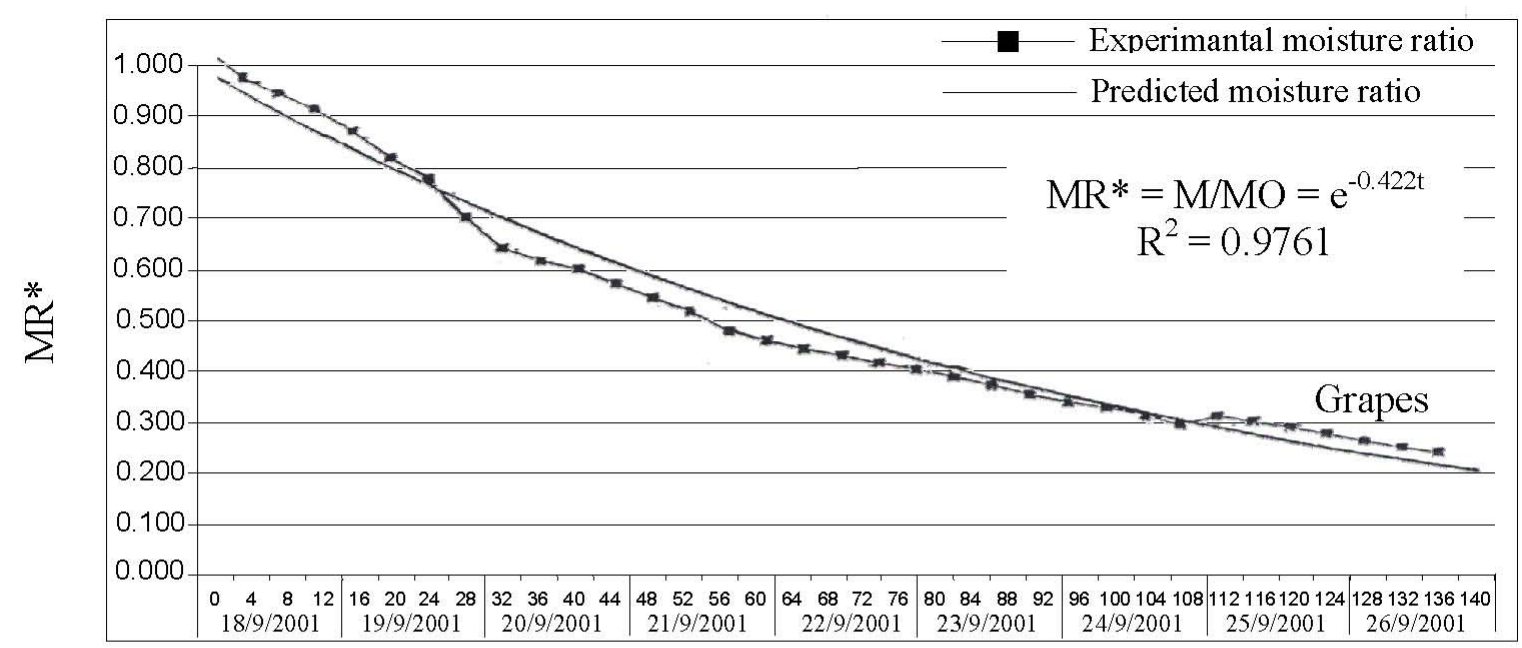

Solar time (hr)

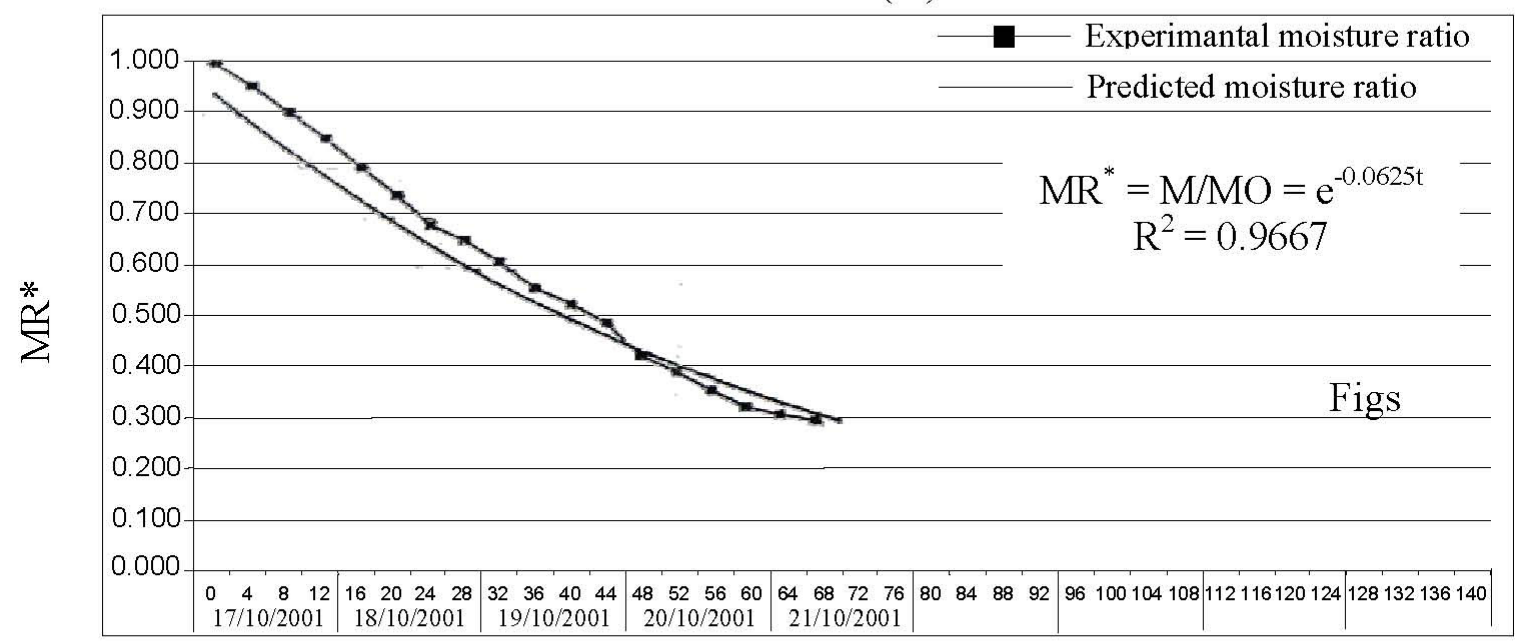

Solar time (hr)

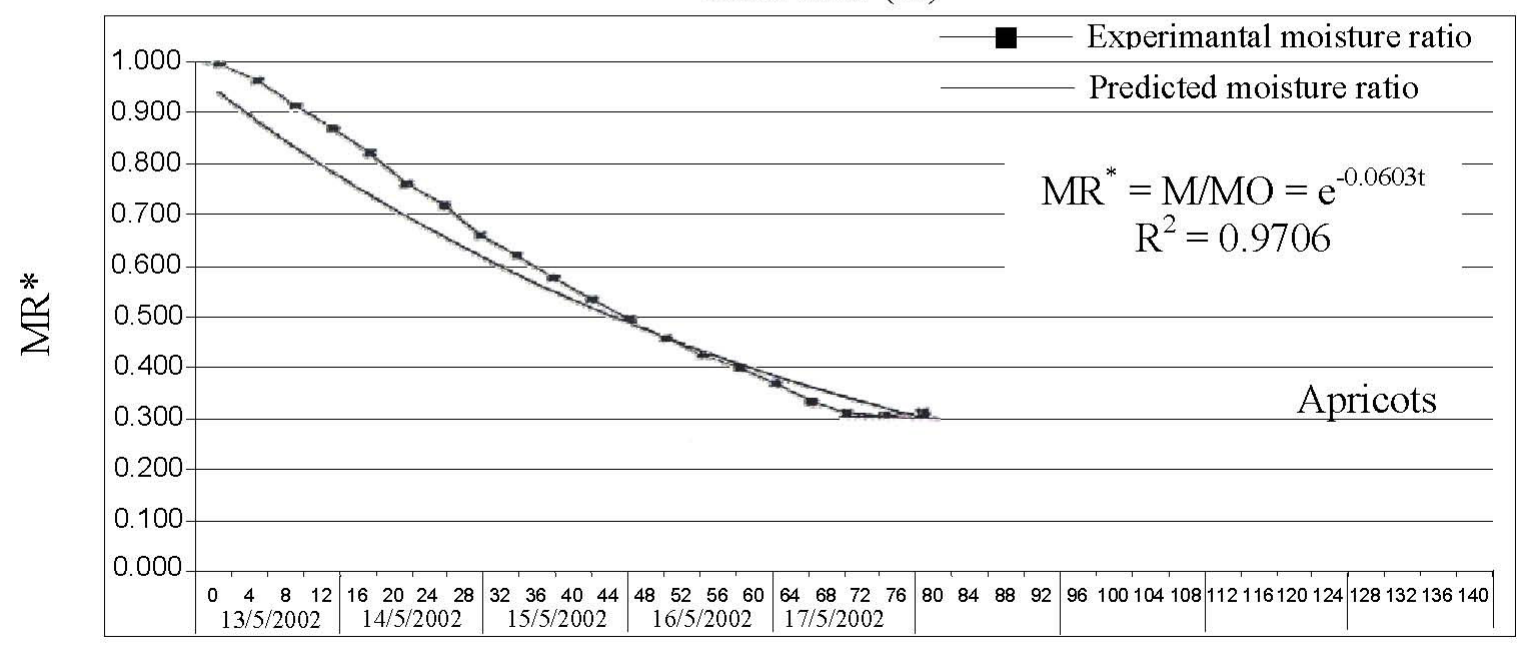

Solar time (hr)

Fig. 2: Corrected moisture ratio MR*, versus accumulated solar drying time (hr) for drying some fruits 


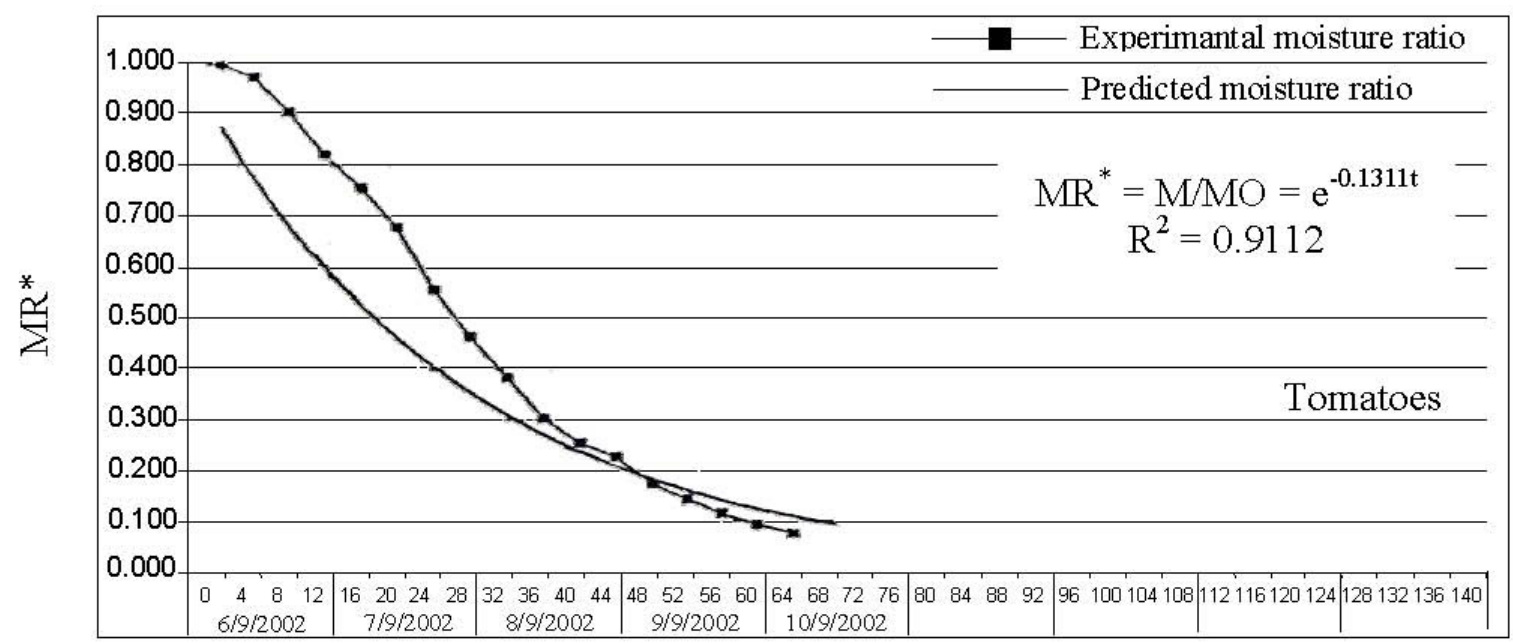

Solar time (hr)

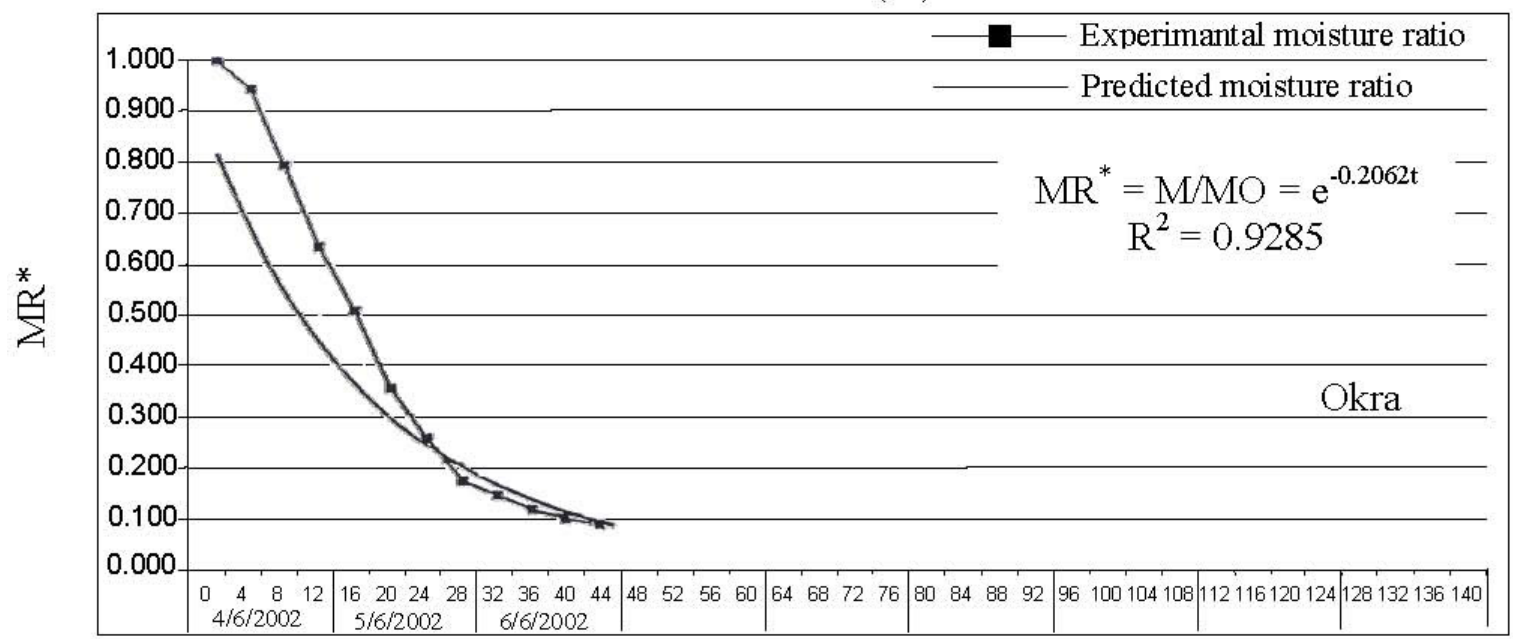

Solar time (hr)

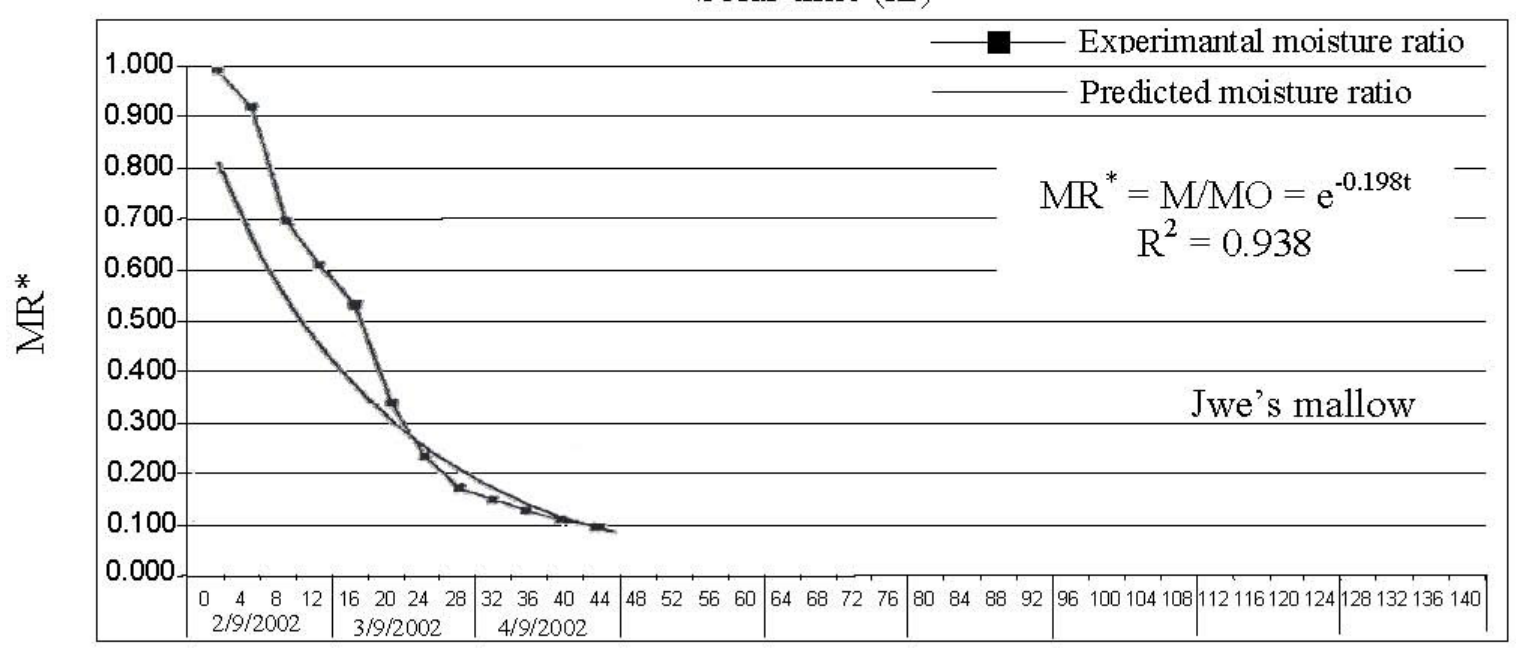

Solar time (hr)

Fig. 3: Corrected moisture ratio MR*, versus accumulated solar drying time (hr) for drying some vegetables 
Table 2: Dehydration and rehydration ratios of fruits and vegetables dried by three different methods

\begin{tabular}{|c|c|c|c|c|c|c|}
\hline \multirow{3}{*}{$\begin{array}{l}\text { Materials } \\
\text { Fruits: }\end{array}$} & \multicolumn{6}{|c|}{ Drying methods } \\
\hline & \multicolumn{2}{|c|}{ Solar drying } & \multicolumn{2}{|c|}{ Hot air } & \multicolumn{2}{|c|}{ Sun drying } \\
\hline & D. $\mathbf{R}$ & R.R & D.R & R.R & D.R & R.R \\
\hline Grapes & $3.62^{\mathrm{a}}: 1$ & $1: 3.33^{\mathrm{a}}$ & $3.75^{\mathrm{a}}: 1$ & $1: 3.42^{\mathrm{a}}$ & $3.70^{\mathrm{a}}: 1$ & $1: 3.20^{\mathrm{a}}$ \\
\hline Figs & $3.67^{\mathrm{a}}: 1$ & $1: 3.52^{\mathrm{a}}$ & $3.49^{\mathrm{a}}: 1$ & $1: 3.30^{\mathrm{a}}$ & $3.75^{\mathrm{a}}: 1$ & $1: 3.38^{\mathrm{a}}$ \\
\hline Apricots & $4.24^{\mathrm{a}}: 1$ & $1: 3.59^{\mathrm{a}}$ & $4.35^{\mathrm{a}}: 1$ & $1: 3.63^{\mathrm{a}}$ & $3.89^{\mathrm{a}}: 1$ & $1: 3.34^{\mathrm{a}}$ \\
\hline \multicolumn{7}{|l|}{ Vegetables: } \\
\hline Tomatoes & $9.94^{\mathrm{a}}: 1$ & $1: 6.86^{\mathrm{a}}$ & $10.35^{\mathrm{a}}: 1$ & $1: 6.93^{\mathrm{a}}$ & $10.40^{\mathrm{a}}: 1$ & $1: 6.78^{a}$ \\
\hline Okra & $9.89^{\mathrm{a}}: 1$ & $1: 6.14^{\mathrm{a}}$ & $9.42^{\mathrm{a}}: 1$ & $1: 6.23^{\mathrm{a}}$ & $9.75^{\mathrm{a}}: 1$ & $1: 6.07^{\mathrm{a}}$ \\
\hline Jew's mallow & $8.86^{\mathrm{a}}: 1$ & $1: 6.58^{\mathrm{a}}$ & $8.52^{\mathrm{a}}: 1$ & $1: 6.65^{\mathrm{a}}$ & $8.92^{\mathrm{a}}: 1$ & $1: 6.56^{\mathrm{a}}$ \\
\hline
\end{tabular}

D.R : Dehydration ratios

elasticity of the cell walls and coagulate protein to reduce their water holding capacity. Foods that dried under optimum conditions suffer less damage and rehydrate more rapidly and to a greater extent than poorly dried foods. Rapid drying at high temperature cause greater changes as compared to moderate rates of drying and lower temperature. The three methods of drying applied here were conducted at up to $60^{\circ} \mathrm{C}$ and thereby, the physical properties of the products did not change significantly.

\section{Chemical composition}

Chemical composition of dried fruits and vegetables are given in Tables (3) and (4). Total sugars and reducing sugars of fruits and vegetables did not exhibit any significant differences as a result of drying by any of the three drying methods. During the $1^{\text {st }}$ step of drying, the natural $\alpha$ and $\beta$ amylases actviate and react with the freshly gelatinized starch, decreasing iodine blue value, and producing dextrins, maltose and glucose. Then these effects decrease possibly as water decreases and denaturation of enzymes occurs (Richardson \& Finaley, 2003). Total acidity and fixed acidity of dried fruits and vegetables investigated here being insignificantly different. In contrast, significant differences could be traced regarding volatile acidity of vegetable crops dried by the different methods utilized in the present study. Moreover, the differences between $\mathrm{pH}$ values were insignificant. No significant differences could be figured out in the content of vitamin $\mathrm{C}$ due to the method of drying of grapes. Vitamin $\mathrm{C}$ in figs, apricots and tomatoes samples was destroyed. The results showed that vitamin $\mathrm{C}$ was destroyed as a result of drying process and this agrees with Eheart \& Oldland (1972) who reported that vitamin $\mathrm{C}$ of dried fruits was destroyed by heat. Notwithstanding, it was obvious that vitamin C contents of okra and Jew's mallow samples

\section{R.R : Rehydration ratios}

dried by hot air and solar drying were significantly higher than their counterparts dried by sun- drying. Ascorbic acid is subject to degradation during heating foods in the presence of water (e.g. 1st $^{\text {step }}$ of drying). The least concentration of sulfur dioxide was found in samples dried by sun- drying but the differences were insignificant.

\section{Microbiological properties}

The count of mesophilic aerobic bacteria on nutrient agar (N. A) medium of the dried fruits and vegetables are shown in Table (5). Data revealed that the fruits and vegetables dried by sun- drying had the highest count of bacteria than the samples dried by solar drying and hot air methods. The lower count of bacteria for the samples dried by solar drying and hot air could be attributed to the highest temperature applied by the two methods as explained by Whitfield (2000) who reported that temperature ranging between $37.2^{\circ} \mathrm{C}$ to $71.2^{\circ} \mathrm{C}$ was found to effectively kill bacteria.

Data of yeast and mould counts on sabouraud dextrose agar (S.D.A) medium, presented in Table (5) indicated that fruits and vegetables dried by hot air and solar drying had a lower counts of yeast and mould. This may be attributed to the low moisture contents, as found by Scalin (1997) who reported that reducing the moisture content of food to the range between $10 \%$ and $20 \%$ resulted in preventing food from yeast and mould contaminations. But, the highest count of yeasts and moulds of the samples dried by sun-drying could be attributed to the low temperatures along with the long period of drying which make microorganisms grow before the food is adequatly dried (kendall \& Allen, 1998).

\section{Organoleptic properties}

Table (6) shows the obtained data of the organoleptic properties of fruits and vegetables dried by 


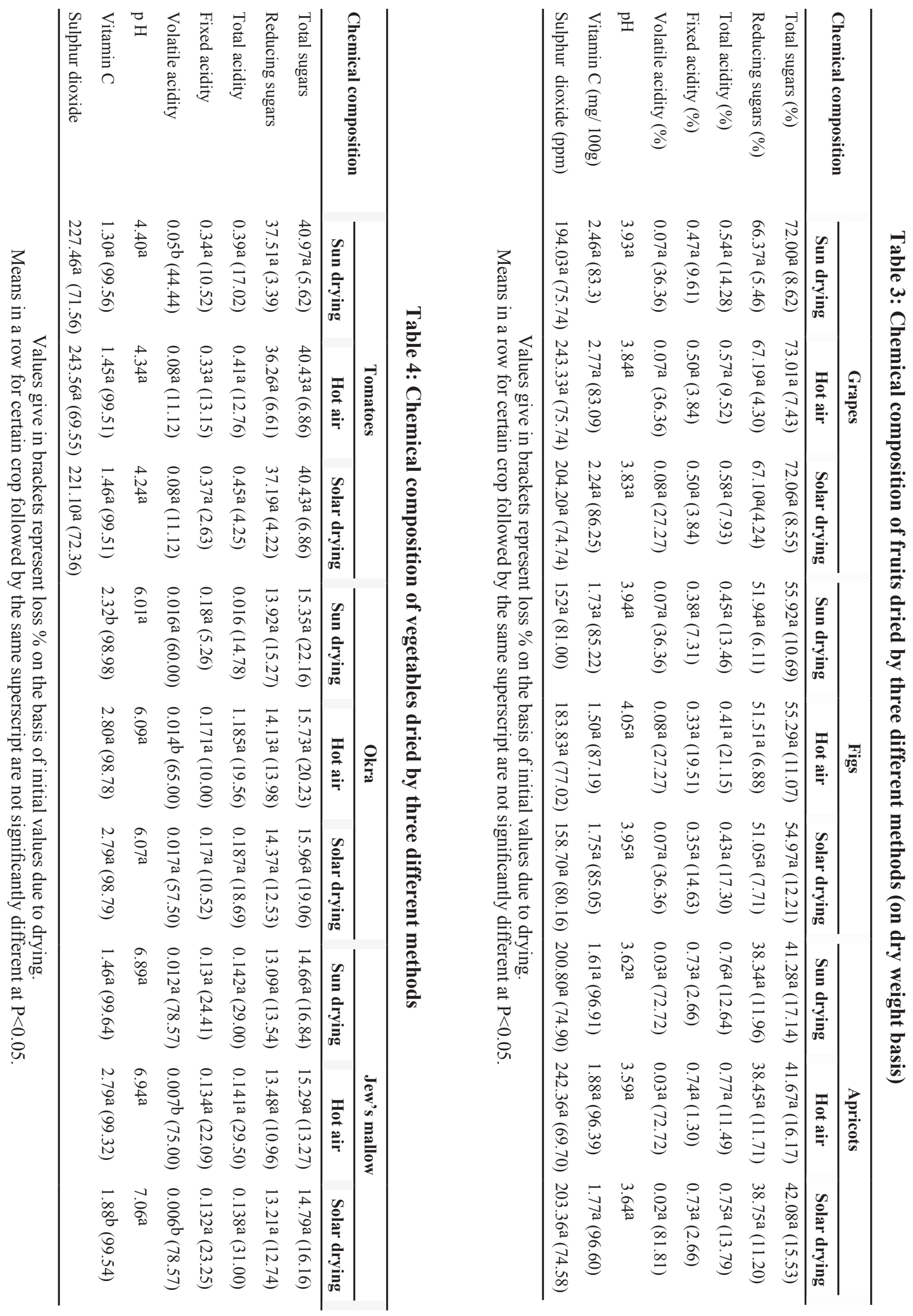


Table 5: Microbiological evaluation of fruits and vegetables dried by three different methods

\begin{tabular}{llcc}
\hline Material & Drying methods & Bacteria (C.F.U) g & Yeasts \& Moulds (C.F.U) g \\
\hline \multirow{3}{*}{ Grapes } & Solar- & $23 \times 10^{2 \mathrm{~b}}$ & $33 \times 10^{2 \mathrm{~b}}$ \\
& Hot air & $12 \times 10^{2 \mathrm{~b}}$ & $87 \times 10^{\mathrm{c}}$ \\
& Sun- & $15 \times 10^{3 \mathrm{a}}$ & $86 \times 10^{2 \mathrm{a}}$ \\
\multirow{3}{*}{ Figs } & Solar- & $16 \times 10^{2 \mathrm{~b}}$ & $21 \times 10^{2 \mathrm{~b}}$ \\
& Hot air & $10 \times 10^{2 \mathrm{~b}}$ & $95 \times 10^{\mathrm{b}}$ \\
& Sun- & $15 \times 10^{3 \mathrm{a}}$ & $10 \times 10^{3 \mathrm{a}}$ \\
\multirow{3}{*}{ Apricots } & Solar- & $79 \times 10^{\mathrm{b}}$ & $11 \times 10^{2 \mathrm{~b}}$ \\
& Hot air & $55 \times 10^{\mathrm{b}}$ & $16 \times 10^{2 \mathrm{c}}$ \\
& Sun- & $17 \times 10^{3 \mathrm{a}}$ & $93 \times 10^{3 \mathrm{a}}$ \\
\multirow{3}{*}{ Tomatoes } & Solar- & $18 \times 10^{2 \mathrm{~b}}$ & $17 \times 10^{2 \mathrm{~b}}$ \\
& Hot air & $14 \times 10^{2 \mathrm{~b}}$ & $13 \times 10^{2 \mathrm{~b}}$ \\
& Sun- & $13 \times 10^{3 \mathrm{a}}$ & $51 \times 10^{2 \mathrm{a}}$ \\
\multirow{3}{*}{ Okra } & Solar- & $29 \times 10^{2 \mathrm{~b}}$ & $10 \times 10^{2 \mathrm{~b}}$ \\
& Hot air & $39 \times 10^{2 \mathrm{~b}}$ & $17 \times 10^{2 \mathrm{~b}}$ \\
& Sun- & $16 \times 10^{3 \mathrm{a}}$ & $71 \times 10^{2 \mathrm{a}}$ \\
& Solar- & $12 \times 10^{2 \mathrm{~b}}$ & $23 \times 10^{2 \mathrm{~b}}$ \\
Jew's mallow & Hot air & $82 \times 10^{\mathrm{b}}$ & $12 \times 10^{2 \mathrm{~b}}$ \\
& Sun- & $13 \times 103 \mathrm{a}$ & $17 \times 10^{3 \mathrm{a}}$ \\
\hline
\end{tabular}

Means followed by the same superscript (in a column, for the same crop) are not significantly different at $\mathrm{P}<0.05$.

Table 6: Sensory evaluation of fruits and vegetables dried by three different methods

\begin{tabular}{|c|c|c|c|c|}
\hline Material & Drying methods & Colour & Flavour & Texture \\
\hline \multirow{3}{*}{ Grapes } & Solar- & $7.82^{\mathrm{a}}$ & $8.36^{\mathrm{a}}$ & $7.72^{\mathrm{a}}$ \\
\hline & Hot air & $8.18^{\mathrm{a}}$ & $8.18^{a}$ & $7.63^{a}$ \\
\hline & Sun- & $5.90^{b}$ & $8.18^{\mathrm{a}}$ & $7.45^{\mathrm{a}}$ \\
\hline \multirow{3}{*}{ Figs } & Solar- & $7.31 \mathrm{a}$ & 6.94 a & $6.87^{\mathrm{a}}$ \\
\hline & Hot air & $7.12 \mathrm{a}$ & $7.01 \mathrm{a}$ & 6.73 a \\
\hline & Sun- & $7.01^{\mathrm{a}}$ & $6.86^{\mathrm{a}}$ & $6.81^{\mathrm{a}}$ \\
\hline \multirow{3}{*}{ Apricots } & Solar- & $7.90^{\mathrm{a}}$ & $7.09 a$ & 6.72 a \\
\hline & Hot air & $7.27 \mathrm{ab}$ & $7.27 \mathrm{a}$ & $6.72^{\mathrm{a}}$ \\
\hline & Sun- & $6.45^{b}$ & 7.27 a & $6.90^{\mathrm{a}}$ \\
\hline \multirow{3}{*}{ Tomatoes } & Solar- & $7.80^{\mathrm{a}}$ & $7.54^{\mathrm{a}}$ & $7.45^{\mathrm{a}}$ \\
\hline & Hot air & $7.27 \mathrm{ab}$ & $8.00^{\mathrm{a}}$ & 8.09 a \\
\hline & Sun- & $6.54 \mathrm{~b}$ & 7.63 a & 7.72 a \\
\hline \multirow{3}{*}{ Okra } & Solar- & 8.45 a & 8.54 a & $8.81^{\mathrm{a}}$ \\
\hline & Hot air & 8.27 a & $8.54^{\mathrm{a}}$ & $7.81 \mathrm{~b}$ \\
\hline & Sun- & $7.90^{\mathrm{a}}$ & $8.00^{\mathrm{a}}$ & $7.72 b$ \\
\hline \multirow{3}{*}{ jew's mallow } & Solar- & $8.72^{a}$ & $8.45^{\mathrm{a}}$ & $8.36^{\mathrm{a}}$ \\
\hline & Hot air & 8.18 ab & $8.36^{a b}$ & $8.00 \mathrm{ab}$ \\
\hline & Sun- & $7.54 \mathrm{~b}$ & $7.54 \mathrm{~b}$ & $7.27 \mathrm{~b}$ \\
\hline
\end{tabular}

Means followed by the same superscript (in a column, for the same crop) are not significantly different at $\mathrm{P}<0.05$. 
the three different drying methods under investigation. It was obvious that the organoleptic properties (colour, flavour and texture) were significantly influenced by the drying methods that were applied with the exception of dried grapes by sun - drying which had the lowest acceptance as judged by panelists, since it gained significantly lower score as compared to grapes dried by solar-drying or hot air methods. It was reported that the best overall quality of dried foods is obtained at a constant temperaturs of about $60^{\circ} \mathrm{C}$ during drying. The pigments degrade above $60^{\circ} \mathrm{C}$ and stability to thermal degradation increases as $\mathrm{pH}$ decreases (Oliveira \& Oliveira, 1999).

\section{REFERENCES}

A.O.A.C 1984. Official Methods of Analysis of the Association of Official Analytical Chemists 14th Ed. Association of Official Analytical Chemists, Inc., Washington, DC. U.S.A.

Adom, K.K., Dzogbefia., V.P., \& Ellis, W.O. 1997 Combined effect of drying time and slice thickness on the solar drying of okra.J.Sci. Food Agric., 73 : 315-320.

Ahmed, M., \& Khan, A.S. 1997. Design and construction of solar grain and fruit drying system. Agric. Mechanization In Asia, Africa and Latin America, 28 (4):62-66.

Bhutani, V.P., \& Sharma, Y.P. 1988. Studies on the drying of apricot grown under dry temperature condition. Indian Food Packer, 42 (4): 83-88.

Carpi, G., Squarcina, N., \& Rovera, P. 1999. Drying of seedless grapes without use of dewaxing agents. Industria Conserva, 74 (4) : 387-391.

Diamant, L.M., \& Muncro, P.A. 1991. Mathematical modelling of hot air drying of sweet potato slices, Int. J. of Food Science and Tech. 26: 99

Difico's Manual 1984. Manual of Dehydrated Culutre and Reagents for Microbiology. Detroit, Michigan, Michigan, USA.

Egan, H., Krik, R.S. \& Sawyer, R. 1981. Pearson's Chemical Analysis of Food. Churchill Livingstone, Edinburgh London, Melbourne and New York, pp 591.

Eheart, M.S., \& Oldland, D. 1972. Storage of fresh broccoli and green beans: Effect on ascorbic acid, sugars and total acids. J. Am diet Assos, 60 : $402: 404$.

El Shiaty, M. A., Muller, J. \& Muhlbeuer, W. 1991. Drying fruits and vegetables with solar energy in Egypt. Agricultural Mechanization in Asia, Africa and Latin America, 22 (4): 61-64.
Goswami, D.Y., Lavania, A., Shahbazy, S. \& Masood, M. 1991. Analysis of a geodesic dome solar fruit dryer. Drying Technology, 9 (3): 677-691.

Gouda, M.S.M. 1974. Chemical and Technology Study on Imported Fig Varieties Plants in Egypt. M. Sc. Thesis. Fac. Agric. Alex. Univ. Alex. Egypt.

Kendall, P. \& Allen, L. 1998. Drying Food. Colorado State Univ. Cooperative Extension No. 9: 309.

Kordylas, J.M. 1991. Processing and Preservation of Tropical and Subtropical foods. ELBS, Mac millan, Hong Kong.

Kosteropoulos, A.E., \& Saravacos, G.D. 1995. Microwave pre- treatment for sun - dried raisins. J. Food. Sci., 60 (2): 344 - 347.

Kramer, A. \& Twigg, B.A. 1962. Fundamentals of Quality Control for the Food Industry. p. 512. The AVI Publishing Co., Inc, West port, Connecticut, USA.

Moyls, A.L. 1986. Evaluation of a solar fruit dryer. Canadian Agricultural Engineering, 28 (2): 137-144.

Oliveira, F.A.R. \& Oliveira, J.C. 1999. Processing Foods : Quality Optimization and Process Assessment. CRC Press. New York, Washington. D.C, USA.

Oschwald, W.R. 1984. Drying Food. UrbanaChempaign Illinois Univ. College of Agri. Cooperative Extension Service, Circular No. 1227. httb://www.ag.uiuc.edu/ visata/htm1_ pubs/DRING/dryfood.htm1

Pangavhane, D.R., Sawhney, R.L. \& Sarsavadia, P.N. 1999. Effects of various dipping pretreatment on drying kinetics of Thonpson seedless graps. J.Fd.Eng., 39 (2): 211-216.

Papoff, C.M., Battacone, G., Agabbio, M., Farris, G.A., Milella, G., Sotgiu, G.M.C., Sanna, F.E., Piga, A. \& D'Aquino, S. 1998. The influence of industrial dehydration on quality of fig fruits. Acta Horticulturae, 480: 233-237.

Richardson, T. \& Finaley, J.W. 2003 .Chemical Changes in Foods during Processing. CBS pub. \& Dist., India.

Saravacos, G.D. 1986. Mass transfer properties of foods. In: M.A. Rao, S.S.H. Rizvi (Ed). Engineering Properties of Foods , pp. 89-132.

Scalin, D. 1997. The design, construction and use of an indirect, through-pass, solar food dryer. Home Power Magazine. Issue No. 57, Feb./ March. 
Shivhare, U.S., Gupta, A., Bawa, A.S., \& Gupta, P. 2000. Drying characteristics and product quality of okra. Drying Technology., $18(1 / 2)$ : 409-419.

Shokr, A.Z. 1974. Analysis of Some Factors Affecting Rice Drying. M. Sc. Thesis Fac. Agric. Alex. Univ. Egypt.

Shokr, A.Z. 1986. A new thin - layer drying equation for rough rice. Misr. J. Ag. Eng., 3 (1): 3-12.

Steel. R.G.D. \& Torrie, T.H. 1980. Principles and Procedures of Statistics. A Biometrical Approach. 2nd Ed. McGraw Hill Inc., USA., p. 120.
Tripathi, R.N. \& Nath, N. 1989. Effect of starch dipping on quality of dehydrated tomato slices. J. Fd. Sci. Tech., 26 (3): 137 - 141.

Von Loesecke, H.W. 1955. Drying and Dehydration of Foods. Chapman and Hal, LTD, London, pp 300.

Whitfield, D.E. 2000. Solar Drying International Conference on Solar cooking, KimberlySouth Africa. 26 $6^{\text {th }} 29^{\text {th }}$ November, 2000.

Yosif, S.S.S. 2002. Development of The Natural Sun Drying System of Marigold Medicinal Plant. M. Sc. Thesis. Fac. Agric. Alex. Univ. Alex. Egypt.

\section{محلدات جودة بعض محاصيل الفاكهة والخضر المحفوظة بثلاث طرق تجفيف مختلفة}

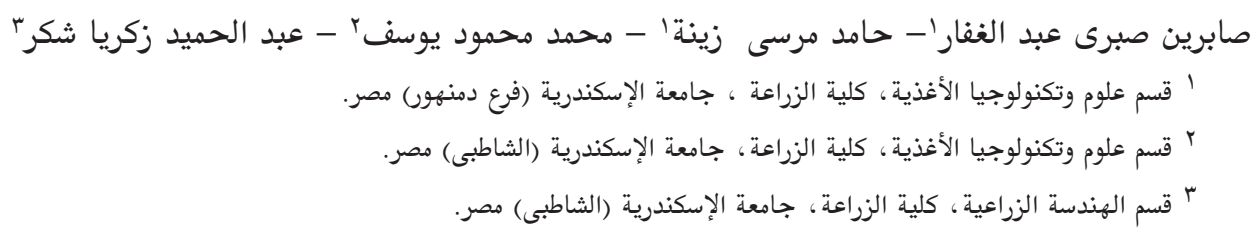

أجري هذا البحث بغرض المقارنة بين ثلاث طرق مختلفة للتجفيف (الطبيعي، الصناعي بالهواء الساخن، الطاقة الشمسية) وذلك

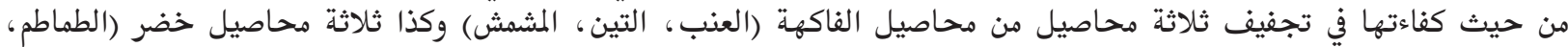
البامية ، الملوخية).

ولتحقيق هذا الهدف فقد تم تصميم مجفف يعمل بالطاقة الشمسية وتم تقدير قيمة K (ثابت التجفيف)، R2 (معامل التقدير) لكل

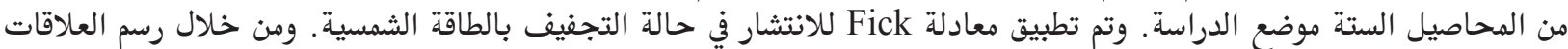
البيانية بين نسب الرطوبة، وقت التجفيف لكل محصول أمكن حساب الزمن الأمثل لتجفيفه بالطاقة الشمسية.

أوضح التحليل الإحصائي عدم وجود فروق جوهرية في قيم معاملي التجفيف والتشرب للمحاصيل الستة التي تم تجفيفها بالطرق

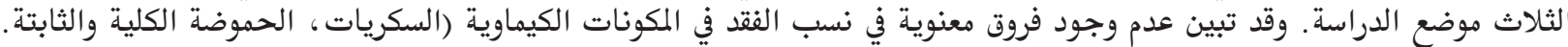

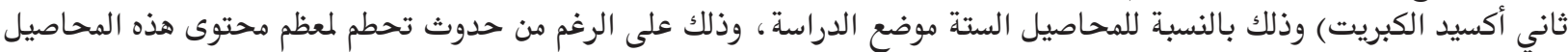

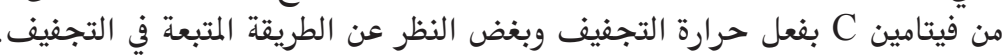

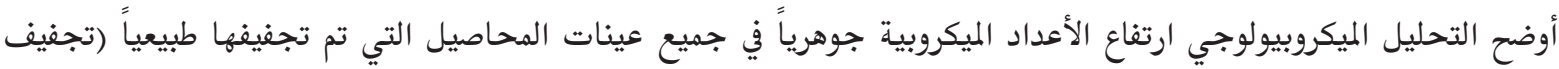

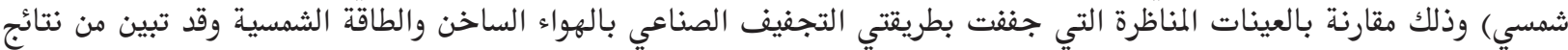

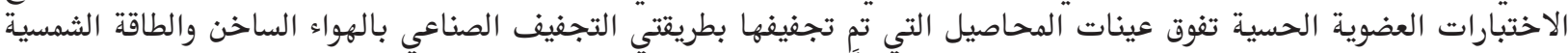

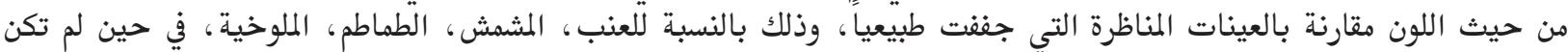

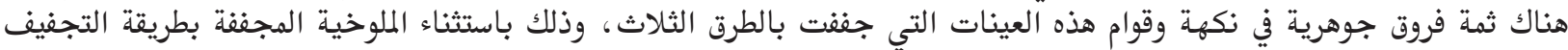
الطبيعي حيث كانت الأقل تقبلا من هذا المنظونه تونه 
